\title{
PERBANDINGAN DAYA DUKUNG ULTIMIT TIANG PANCANG ANTARA METODE TEORETIS DAN METODE AKTUAL DENGAN KONFIGURASI TIANG DAN KEDALAMAN
}

Muhammad Suhaimi ${ }^{1}$, Fathurrozi ${ }^{1}$, M. Aspihani Rahman ${ }^{2}$

${ }^{1}$ Staf Pengajar Jurusan Teknik Sipil Poliban, ${ }^{2}$ Mahasiswa Prodi DIII Teknik Sipil Poliban

\begin{abstract}
Abstrak
Lapisan tanah di Kota Banjarmasin umumnya berupa lempung lunak, sedangkan lapisan tanah keras berada cukup dalam berkisar 35 meter lebih di bawah permukaan tanah. Untuk itu fondasi dalam merupakan pilihan yang tepat bila ingin membangun konstruksi yang lebih kuat dan stabil,. Penelitian ini bertujuan untuk mengetahui nilai perbanding daya dukung tiang berdasarkan teoritis dan aktual sehingga dapat digunakan sebagai pertimbangan dalam menentukan pilihan untuk perencanaan maupun pelaksanaan pemancangan tiang fondasi.

Penelitian dilakukan di lingkungan Kampus ULM Jl. Brigjen H. Hasan Basri (Kayu Tangi) Banjarmasin. Penelitian ini menggunakan tiang mini pile beton bertulang dengan ukuran $20 \mathrm{~cm} \times 20 \mathrm{~cm}$ dengan panjang 12 meter dan 18 meter. Untuk perhitungan teoretis menggunakan data uji sondir, sedangkan untuk daya dukung aktual diperoleh dari data hasil loading test di lapangan pada tiang B,G, E dan I, kemudian pengolahan datanya menggunakan metode Davisson (1973), Mazurkiewich (1973) dan Chin (1970).

Hasil perhitungan daya dukung tiang ultimit, baik teoritis maupun aktual menunjukan perbedaan yang sangat signifikan. Perbedaan yang sangat besar terjadi pada tiang E4 dengan kedalaman 12 meter sebesar 53,25\%, dan perbedaan yang paling kecil terjadi pada tiang I dengan kedalaman 12 meter sebesar $15,25 \%$.
\end{abstract}

Kata kunci : Tiang Pancang, Daya dukung, Teoretis dan actual

\section{ABSTRACT}

The soil layers in Banjarmasin are generally soft clay soil, whereas hard soil layers are in the range of 30 to 50 matters below ground level. Therefore, deep foundation is the right alternative to build a stronger and more stable construction. This study aims to determine the comparison value of pile bearing capacity based on theoretical and actual result so it can be used to determine the selection for planning and execution in installation of piles foundation.

The study was conducted at Lambung Mangkurat University (ULM) Campus, Jl. Brigjend H. Hasan Kayu Tangi, Banjarmasin. This study used mini piles size of $20 \mathrm{~cm} x 20 \mathrm{~cm}$ with vary in length. The type of soil bearing capacity against piles is friction. In theoretical calculation, it used sondir data while in actual bearing capacity it used the result from loading data test at pile $B, E, G$ and $I$, then all data processed and analyzed by using methods from Davission (1973), Mazurkiewich (1973), and Chin (1970).

The results of the calculation of bearing capacity of the ultimit piles, both theoretical and actual show a very significant difference. A very large difference on pile E4 with a depth of 12 meters of $53,25 \%$, and the smallest difference in pile I with a depth of 12 meters by 15,25\%.

Keywords: Pile, Bearing Capacity, Theoretical and actual 


\section{PENDAHULUAN}

Banjarmasin adalah ibu kota Provinsi Kalimantan Selatan, kondisi permukaan tanah aslinya didominasi oleh rawa monoton, dan lapisan tanah di bawahnya berupa tanah lempung lunak. Menurut data laboratorium uji tanah Poliban (2015), lapisan tanah keras di Banjarmasin mencapai kedalaman 35 meter lebih. Khusus untuk bangunan yang besar dan bangunan yang lebih banyak menerima beban dinamis, maka fondasi tiang adalah alternatif pilihan yang paling tepat untuk mengatasinya. Fondasi tiang pancang digunakan untuk mendukung bangunan bila lapisan tanah tanah yang kuat terletak sangat dalam (Hardiyatmo, 2015). Sedangkan menurut Sardjono (1991) fondasi tiang pancang berfungsi untuk memindahkan beban di atasnya (upper structure) kelapisan tanah yang lebih dalam. Untuk konstruksi beban berat (high-rise building) biasanya jenis pondasi dalam adalah menjadi pilihan, dan secara umum permasalahan perencanaan pondasi dalam lebih rumit dari pondasi dangkal (Noor dan Octavian, 2014).

Permasalahan yang sering terjadi dalam perencanaan daya dukung tiang pancang adalah mempunyai perbedaan yang sangat besar antara satu metode dengan metode yang lain. Hal ini disebabkan kurang validnya data-data lapangan, baik uji sondir atau Cone Penetration Test (CPT) maupun Standard Penetration Test (SPT), begitu juga dengan perhitungan aktual, jarang dilakukan sebagai bahan perbandingan dalam perhitungan. Penelitian ini bertujuan untuk mengetahui besarnya daya dukung ultimit berdasarkan metode teoretis dan aktual dan berapa besar perbedaannya dari kedua metode tersebut. Oleh sebab itu, dengan dilakukannya penelitian ini, hasil dan manfaatnya diharapkan dapat dijadikan acuan dalam menghitung atau mendesain tiang pancang, sehingga kesalahan hasil perhitungan cara teoretis dapat dikoreksi dengan hasil cara aktual di lapangan.

Dalam penelitian ini digunakan beberapa metode untuk perhitungan dan pengolahan datanya. Untuk perhitungan daya dukung teoretis menggunakan metode Schmertmann-Nottingham (1975), sedangkan untuk perhitungan dan pengolahan data aktual menggunakan 3 metode, yaitu: (1) metode Davisson (1973); (2) metode Mazurkiewich (1973); dan (3) metode Chin (1970). Untuk metode teoretis, datanya diperoleh dari hasil tes sondir di lapangan, sedangkan metode aktual datanya diperoleh dari hasil loading test.

Fondasi tiang pancang digunakan untuk mendukung bangunan bila lapisan tanah tanah yang kuat terletak sangat dalam (Hardiyatmo, 2015). Fondasi tiang pancang berfungsi untuk memindahkan beban di atasnya (upper structure) ke lapisan tanah yang lebih dalam (Sarjono, 1991).

Menurut cara pemindahan beban, tiang pancang dibagi 2, yaitu: (1) tiang pancang yang bertahan di ujungnya (point bearing pile); (2) tiang pancang yang sebagian besar ditimbulkan oleh gesekan antara tiang pancang dengan tanah sekitarnya, tiang pancang seperti ini disebut friction pile. (Sarjono, 1991).

Tujuan dari penelitian ini adalah menghitung berapa nilai daya dukung tiang pancang berdasarkan teoretis menggunakan data uji sondir, menghitung nilai daya dukung tiang pancang berdasarkan metode aktual menggunakan data hasil loading test, dan melakukan perbandingan antara hasil perhitungan menggunakan cara teoretis dan aktual.

\section{METODE PENELITIAN}

Metode Teoretis

Uji sondir dilaksanakan untuk mengetahui perlawanan penetrasi konus dan hambatan pelekat pada setiap kedalaman (Shirley, 1987).

Metode Schmertmann

Untuk daya dukung ultimit tiang menggunakan rumus :

$$
\begin{aligned}
& Q_{p}=Q_{u}=C_{n r} \quad-r \quad \times A_{\text {ujung tiang }} \\
& C_{n r} \quad-r \quad=\frac{\frac{1}{2}\left(\overline{C_{n 1}}+\overline{C_{n 2}}+\overline{C_{n 3}}\right.}{2}
\end{aligned}
$$

Dimana ;

$\overline{C_{n 1}}=$ harga rata-rata konus dihitung mulai dari ujung tiang sampai $4 \mathrm{D}$ ke bawah.

$\overline{C_{n 2}}=$ harga rata-rata dari konus minimum dihitung mulai dari ujung tiang sampai 4D ke bawah.

$\overline{C_{n 3}}=$ harga rata-rata konus minimum dihitung mulai dari ujung tiang sampai $8 \mathrm{D}$ ke atas.

Untuk menentukan perlawanan akibat friction, menurut Metode Schmertmann dan Nottingham sebagai berikut:

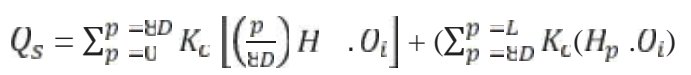

Dimana :

$Q_{S}=$ daya dukung ultimit tiang pancang akibat hambatan lekat/friction sepanjang mantel tiang.

$K_{c}=$ faktor koreksi untuk clay

$K_{s}=$ faktor koreksi untuk sand

$p=$ kedalaman ruas yang ditinjau (i)

$H_{p}=$ hambatan pelekat untuk ruas pada kedalaman pi

$O_{i}=$ keliling tiang untuk ruas kedalaman $p i$ 
$L=$ total panjang tiang pancang yang terbenam dalam tanah

(Harga $K_{c}$ dan $K_{s}$ didapat dari gambar 3.2)

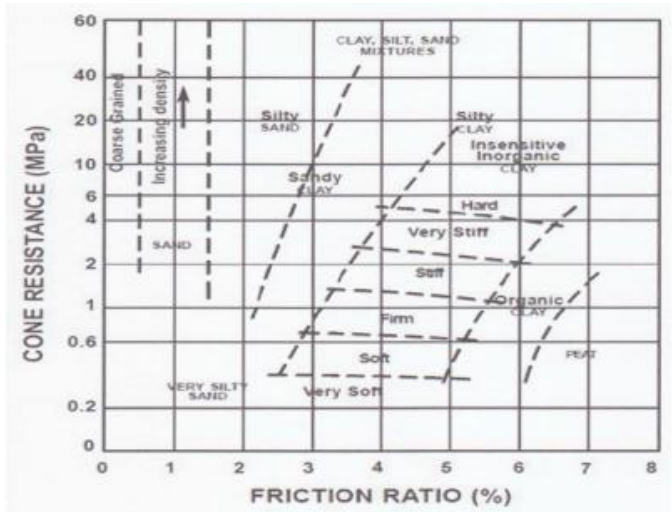

Gambar 1 Grafik Klasifikasi tanah menurut Schmertmann (sumber : Noor dan Octavian, 2014)

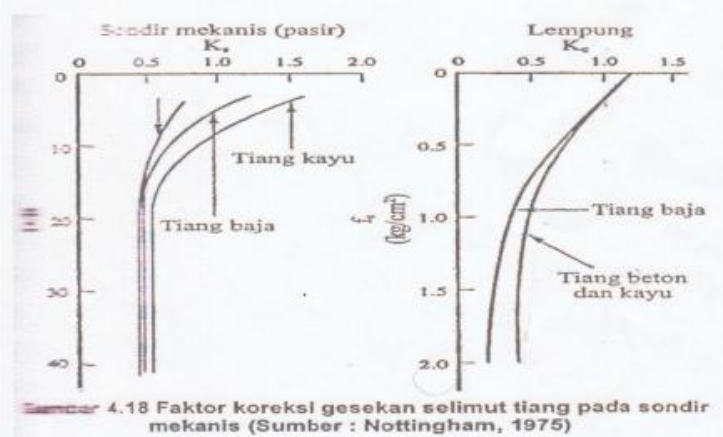

Gambar 2. Faktor koreksi gesekan pada selimut tiang pada batang sondir (sumber : GEC UNPAR, 2005)

Uji Pembebanan (Loading Test)

Pada umumnya, kapasitas dukung tiang dihitung berdasarkan sifat-sifat tanah. Pada awal pembangunan, uji beban tiang dilakukan untuk membuktikan apakah hasil hitungan yang diperoleh tersebut dapat dipertanggungjawabkan. (Hardiyatmo, 2015).

\section{Metode Davisson}

Prosedur penentuan beban ultimit dari pondasi tiang menurut Manual Fondasi Tiang GEC UNPAR (2013) adalah sebagai berikut :

a. Diplot kurva beban terhadap penurunan

b. Penurunan elastis dihitung dengan rumus :

$$
\frac{S_{E}}{Q}=\frac{L}{A}
$$

c. Tarik garis OA berdasarkan persamaan penurunan elastis $\left(S_{e}\right)$

d. Tarik garis BC sejajar dengan garis OA dengan jarak $\mathrm{X}$, dimana :

$$
\mathrm{X}=0,15+\frac{D}{1} \text { inch }
$$

e. Perpotongan antara kurva load settlement dengan garis lurus merupakan daya dukung ultimit.

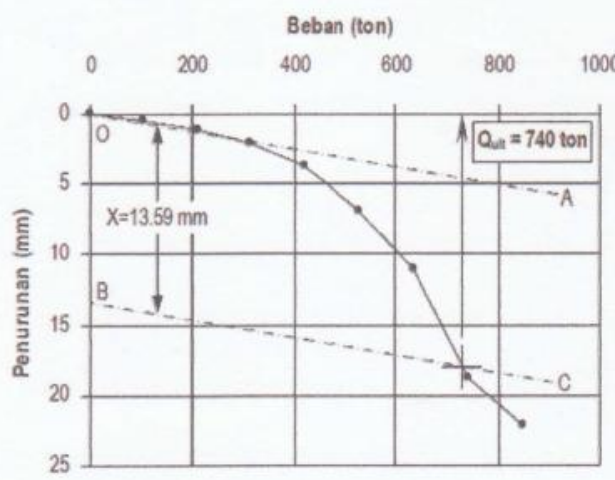

Gambar 3. Interprestasi beban ultimit (Metode Davisson) (sumber : GEC UNPAR, 2005)

Metode Mazurkiewich

Prosedur penentuan beban ultimit pondasi tiang menggunakan metode Mazurkiewich menurut Manual Fondasi Tiang GEC UNPAR (2005) adalah sebagai berikut :

a. Diplot kurva beban uji yang diberikan terhadap penurunan.

b. Tarik garis dari beberapa titik penurunan yang dipilih hingga memotong kurva.

c. Dari perpotongan setiap beban dibuat garis bersudut $45^{0}$ terhadap garis perpotongan berikutnya.

d. Menghubungkan titik-titik yang terbentuk hingga menghasilkan sebuah garis lurus.

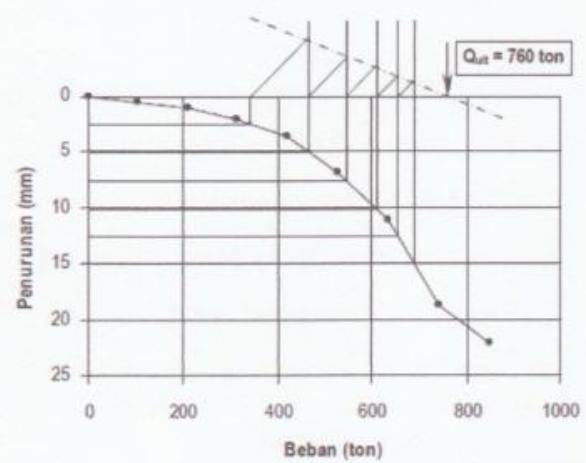

Gambar 4 Interprestasi beban ultimit (Metode Mazurkiewich) (sumber : GEC UNPAR, 2005)

\section{Metode Chin}

Perhitungan beban ultimit pondasi tiang dengan menggunakan metode Chin menurut Manual Fondasi Tiang GEC UNPAR (2005) adalah sebagai berikut :

a. Diplot kurva antara rasio beban terhadap penurunan (s/Q) dengan penurunan.

b. Diperoleh persamaan garis atau dari $\mathrm{s} / \mathrm{Q}=\mathrm{C} 1 . \mathrm{s}+\mathrm{C} 2$ 
c. C1 dihitung dari persamaan garis atau gradient/kemiringan

d. Beban ultimit adalah 1/C1

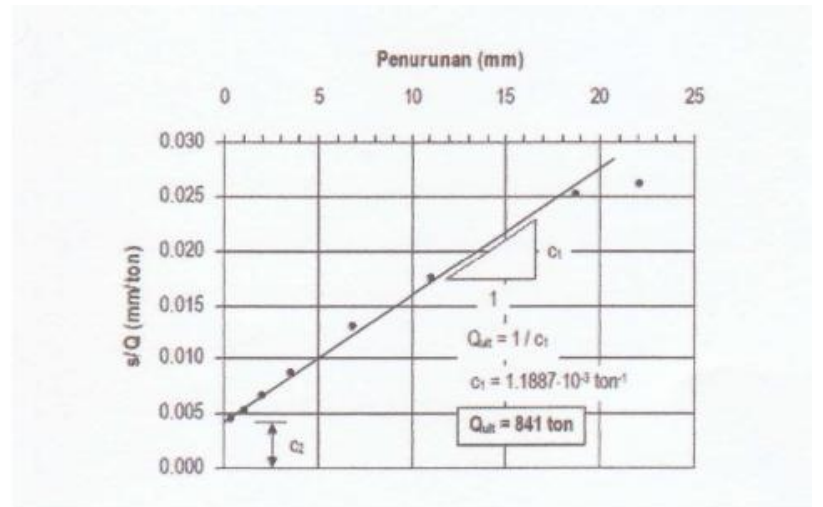

Gambar 5 Interprestasi beban ultimit (Metode Chin) (sumber : GEC UNPAR, 2005)

Penelitian ini menggunakan metode eksperimen, khususnya untuk menentukan daya dukung tiang dengan cara aktual.

Konfigurasi tiang pancang disusun berbeda untuk 2 katagori: (1) konfigurasi B dan E tiang kelompok dengan masing-masing 4 tiang dengan kedalaman berbeda, untuk konfigurasi $\mathrm{B}$ dengan kedalaman 18 meter, konfigurasi E kedalaman 12 meter; (2) konfigurasi I dan $\mathrm{G}$ tiang tunggal, tiang konfigurasi I kedalaman 18 meter dan tiang konfigurasi $\mathrm{G}$ dengan kedalaman 12 meter. Kemudian tiang-tiang tersebut sesuai konfigurasi dan kedalam diberikan beban sampai batas pembebanan tertentu. Dari hasil eksperimen pembebanan, dilakukan pengambilan data, kemudian dilakukan pengolahan dan analisa data.

\section{Lokasi Penelitian}

Lokasi penelitian dilaksanakan di Kampus ULM Jl. Brigjen H. Hasan Basri (Kayu Tangi) Banjarmasin.

Waktu Penelitian

Waktu pelaksanaan penelitian terdiri dari pengambilan data di lapangan seperti uji sondir tanggal 27 Oktober 2015, dan Loading Test tanggal 30 Januari 2016 sampai dengan 10 Februari 2016. Pengolahan dan analisa data tanggal 7 Maret 2016 sampai dengan 3 Juni 2016.

\section{Metode Pelaksanaan}

Tahapan pelaksanaan dalam penelitian ini meliputi, perencanaan, pelaksanaan dan pelaporan. Untuk tahap perencanaan meliputi persiapan peralatan, bahan, instrument, tenaga peneliti dan pendanaan. Tahap pelaksanaan adalah mencari data di lapangan, seperti: (1) Uji Sondir; (2) Loading Test, pengolahan dan analisis data. Sedangkan tahap pelaporan adalah membuat laporan hasil pengolahan, analisis data dan kesimpulan yang berupa hard copy maupun soft copy.

Uji Sondir

Peralatan yang digunakan seperti mesin sondir, satu set batang sondir, manometer kapasitas $50 \mathrm{~kg} / \mathrm{cm}^{2}$ dan $250 \mathrm{~kg} / \mathrm{cm}^{2}$, bikonus dan paten konus, satu set angker, satu set kunci pipa, kunci plunyer, palu, waterpass, kunci manometer dan minyak hidraulik.

Pelaksanaan uji sondir, setelah mesin terpasang dengan kokoh, dilanjutkan dengan memasang batang sondir yang pertama, dibaca dan catat setiap $20 \mathrm{~cm}$ masuk kedalaman tanah pembacaan konus dan bikonus pada manometer. Apabila pembacaan manometer tiga kali berturut-turut menunjukan nilai $>150 \mathrm{~kg} / \mathrm{cm}^{2}$, maka uji sondir dihentikan. Sedangkan untuk penelitian ini dihentikan pada kedalam 28,60 meter, manometer 1 menunjukan angka $100 \mathrm{~kg} / \mathrm{cm}^{2}$ dan manometer 2 menunjukan angka $110 \mathrm{~kg} / \mathrm{cm}^{2}$. Hal ini disebabkan karena panjang tiang untuk loading test hanya 18 meter.

Uji Pembebanan (Loading Test)

Peralatan yang digunakan adalah balok penahan/balok baja $\mathrm{H}$, waterpass, rambu ukur, pemberat/tiang pancang yang sudah ditentukan, tiang pancang mini pile ukuran $20 \mathrm{~cm} \times 20 \mathrm{~cm}$, dengan panjang bervariasi, yaitu: $12 \mathrm{~m}$ dan $18 \mathrm{~m}$.

Pelaksanaan loading test dimulai setelah semua balok $\mathrm{H}$ dan tiang fondasi terpasang dengan baik dan kokoh, serta rata permukaan dengan menggunakan waterpass, serta pemasangan rambu ukur. Setelah itu dimulai dengan meletakan pemberat di atas balok penahan secara vertikal sampai ketinggian tertentu. Pembacaan dilakukan terhadap beban dan waktu, serta pergerakan tiang pada saat sebelum dan sesudah tahapan pembebenan diberikan atau dikurangi dengan selang waktu 30 menit. Jika keruntuhan terjadi, maka dilakukan pembacaan sebelum dilakukan pengurangan beban pertama. Selama proses pengurangan beban (unloading), lakukan pembacaan dengan selang waktu 30 menit.

Pengolahan Data dan Analisa Data

Setelah data-data penelitian diperoleh di lapangan, selanjutnya adalah mengolah dan menganalisa data tersebut. Untuk pengolahan data terdiri dar:

a. Membuat tabulasi

b. Menghitung daya dukung tiang secara teoretis dari data hasil sondir dengan metode SchmertmannNottingham.

c. Menghitung daya dukung tiang aktual dari hasil data loading test menggunakan metode Davisson, Mazukiewich dan Chin. 
Dari hasil pengolahan data, selanjutnya dilakukan analisa data yang meliputi :

a. Daya dukung tiang cara teoritis

b. Daya dukung tiang cara aktual

c. Hitung persentase perbanding cara teoretis dan aktual

d. Kesimpulan

\section{HASIL DAN PEMBAHASAN}

Dari data-data yang diperoleh di lapangan, seperti uji uji sondir dan loading test, selanjutnya dilakukan perhitungan sebagai berikut:

Metode Schmertmann-Nottingham

Untuk menentukan daya dukung ultimit tiang dari data uji sondir berdasarkan cara teoretis adalah sebagai berikut:

Kedalaman 12 meter:

Diameter tiang

4D

: $20 \mathrm{~cm}: 20 \mathrm{~cm}$

$8 \mathrm{D}$

: 4 x $0,20=0,80 \mathrm{~cm}$

Luas Ujung Tiang (A)

$: 8 \times 0,20=1,60 \mathrm{~cm}$

$Q_{C} \quad=4,00 \mathrm{~kg} / \mathrm{cm}^{2}$ (sondir Poliban, 2015)

$H \quad=4,00 \mathrm{~kg} / \mathrm{cm}$ (sondir Poliban, 2015)

$F=5 \% \quad$ (Sondir Poliban, 2015)

$C_{n 1}=$ nilai $q_{c}$ rata-rata $4 \mathrm{D}$ ke bawah

$=4+5+6+4+5 / 5$

$=4,8 \mathrm{~kg} / \mathrm{cm}^{2}$

$Q_{c m}=$ nilai minimum dari 3 data $q_{c}$

$=4,5,6$ (ambil nilai minimum)

$=4 \mathrm{~kg} / \mathrm{cm}^{2}$

$C_{n 2}=$ nilai $q_{c}$ minimum rata-rata dihitung dari ujung tiang sampai 4D ke bawah.

$=4+4+5 / 3$

$=4,3 \mathrm{~kg} / \mathrm{cm}^{2}$

$C_{n 3} \quad=$ nilai dari $q_{c}$ minimum rata-rata dari ujung tiang sampai $8 \mathrm{D}$ ke atas.

$=4+5+4+5+4+3+4+4+3 / 9$

$=4,1 \mathrm{~kg} / \mathrm{cm}^{2}$

$Q_{c r}-r=\{[(4,8+4,3) / 2]+4,1\} / 2$

$=4,33 \mathrm{~kg} / \mathrm{cm}^{2}$

$\mathrm{FR}=5 \%$

$\mathrm{S} / \mathrm{C}=$ didapat dari grafik antara hubungan $q_{c}$ dan FR seperti gambar $3.1=\mathrm{CS}$

$\mathrm{Li} / \mathrm{D}=$ untuk tanah pasir

$\mathrm{Li} / 8 \mathrm{D}=$ untuk tanah lempung $=12 / 1,6=7,5$

Kc.s = didapat dari grafik gambar $3.2=1,00$

$Q_{p} \quad=400(4,33 \times 0,001)$

$=1,73$ ton

$0-8 D=(H P x 0,1 x(\mathrm{Li} / 8 D) \mathrm{Kc} . \mathrm{s} \mathrm{x}$ keliling penampang tiang $)$ + nilai di atasnya. (catatan : hanya kedalaman 8D, nilai selanjutnya sama dengan kedalaman 8D.

$$
=1,10 \text { ton }
$$

$(8 D-L)=H P \times 0,1 \times K c . s \times$ keliling penampang tiang + nilai di atasnya.

$=6,56$ ton

$Q_{s} \quad=0-8 D+(8 D-L)$

$=1.10+6,56$

$=7,66$ ton

$Q_{u} \quad=Q_{p}+Q_{s}$

$=1,73+7,66$

$=9,39$ ton

Kedalaman 18 meter:

1. Diameter tiang

$: 20 \mathrm{~cm}: 20 \mathrm{~cm}$

2. $4 \mathrm{D}$

: 4 x $0,20=0,80 \mathrm{~cm}$

3. $8 \mathrm{D}$

: $8 \times 0,20=1,60 \mathrm{~cm}$

4. Luas Ujung Tiang (A) : $20 \times 20=400 \mathrm{~cm}^{2}=0,04 \mathrm{~m}^{2}$

5. $Q_{C}=9,00 \mathrm{~kg} / \mathrm{cm}^{2}$ (sondir Poliban, 2015)

6. $H=4,00 \mathrm{~kg} / \mathrm{cm}$ (sondir Poliban, 2015)

7. $F=2,2 \% \quad$ (sondir Poliban, 2015)

$C_{n 1}=$ nilai $q_{c}$ rata-rata $4 \mathrm{D}$ ke bawah $=8,4 \mathrm{~kg} / \mathrm{cm}^{2}$

$Q_{c m}=$ nilai minimum dari 3 data $q_{c}$ $=7,8,9$ (ambil nilai minimum) $=7 \mathrm{~kg} / \mathrm{cm}^{2}$

$C_{n 2}=$ nilai $q_{c}$ minimum rata-rata dihitung dari ujung tiang sampai 4D ke bawah.

$=7,7 \mathrm{~kg} / \mathrm{cm}^{2}$

$C_{n 3}=$ nilai dari $q_{c}$ minimum rata-rata dari ujung tiang sampai 8D ke atas

$=7,2 \mathrm{~kg} / \mathrm{cm}^{2}$

$Q_{c r} \quad-r=\{[(8,4+7,7) / 2]+7,2\} / 2$ $=7,6 \mathrm{~kg} / \mathrm{cm}^{2}$

$\mathrm{FR}=2,2 \%$

$\mathrm{S} / \mathrm{C}=$ didapat dari grafik antara hubungan $q_{c}$ dan FR seperti gambar $3.1=\mathrm{CS}$

$\mathrm{Li} / \mathrm{D}=$ untuk tanah pasir

$\mathrm{Li} / 8 \mathrm{D}=$ untuk tanah lempung $=18 / 1,6=11,25$

$K c . s=$ didapat dari grafik gambar $3.2=1,00$

$Q_{p} \quad=400(7,60 \times 0,001)$

$=3,04$ ton

$0-8 D=(H P x 0,1 x(\mathrm{Li} / 8 D) \mathrm{Kc} . \mathrm{s} \mathrm{x}$ keliling penampang tiang $)$ + nilai di atasnya. (catatan : hanya kedalaman $8 \mathrm{D}$, nilai selanjutnya sama dengan kedalaman $8 \mathrm{D}$. $=1,10$ ton

$(8 D-L)=H P \times 0,1 \times K c . s \times$ keliling penampang tiang + nilai di atasnya.

$=11,20$ ton

$Q_{s} \quad=0-8 D+(8 D-L)$ 
$=1.10+11,20$

$=12,30$ ton

$Q_{u} \quad=Q_{p}+Q_{s}$

$=3,04+12,30$

$=15,34$ ton

Daya Dukung Aktual

Pembahasan perhitungan daya dukung aktual hasil loading test akan disajikan dalam bentuk gambar/grafik untuk 3 metode, yaitu metode Davisson, metode Mazurkiewich dan metode Chin. Sebagai contoh disini hanya disajikan gambar/grafik tiang B1, sedangkan untuk semua tiang yang lain, hasilnya disajikan dalam bentuk tabel.

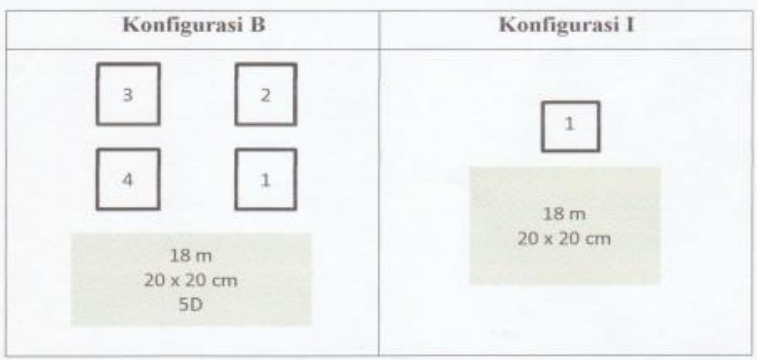

Tabel 4.4 Mapping Klasifikasi Tiang

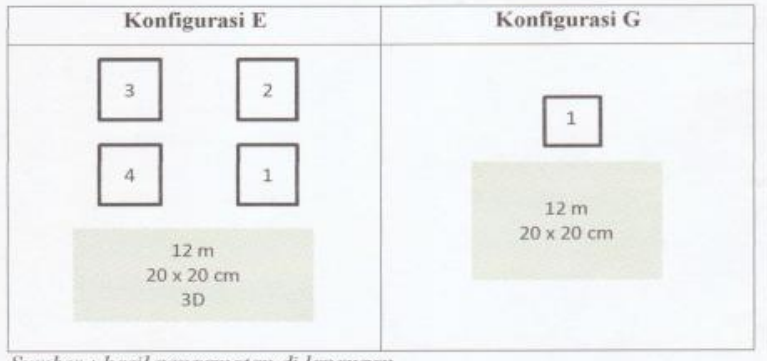

Gambar 6 Mapping Konfigurasi Tiang
Daya Dukung Tiang Berdasarkan Data Loading Test

\section{Tiang Konfigurasi B1}

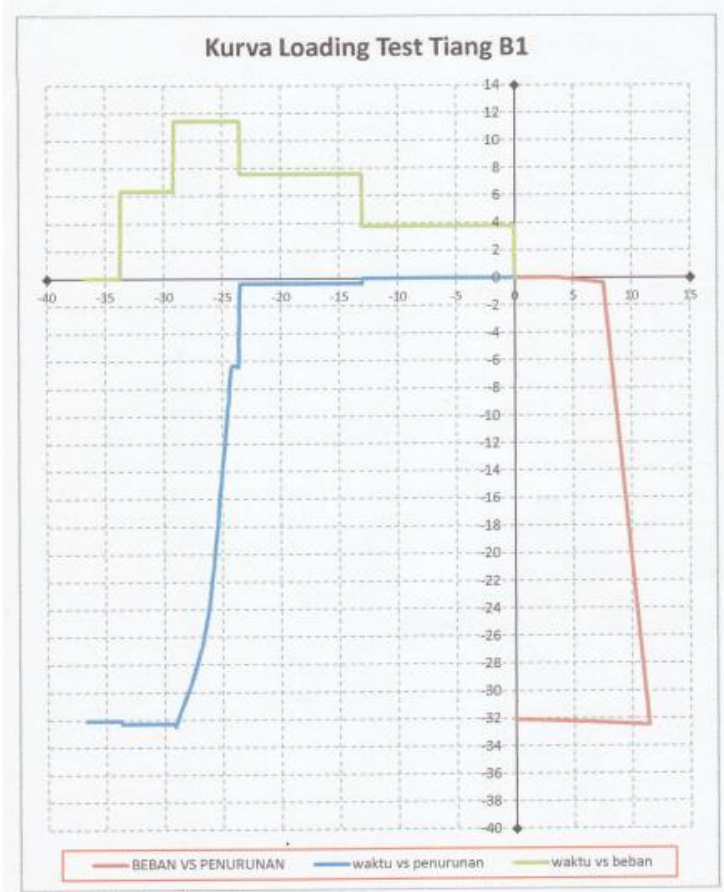

Sumber : hasil perhitungan

Gambar 7 Kurva Hasil Loading Test Tiang B1

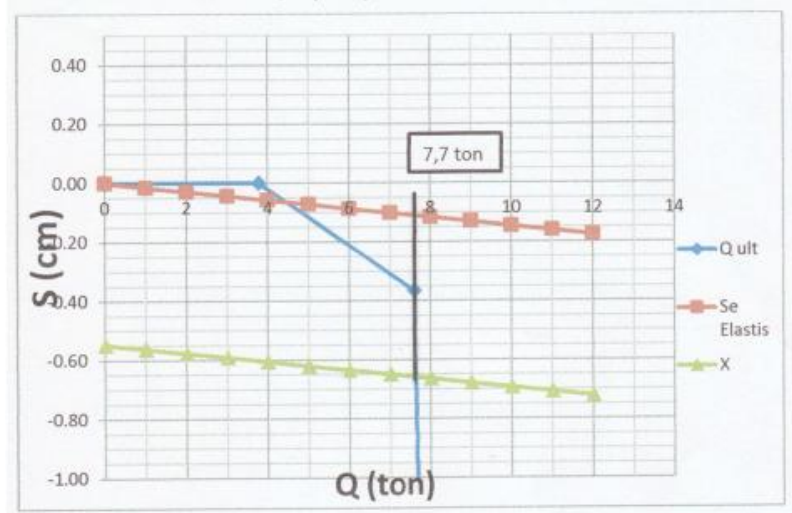

Sumber : hasil perhitungan

Gambar 8 Daya Dukung Tiang B1 Metode Davisson 


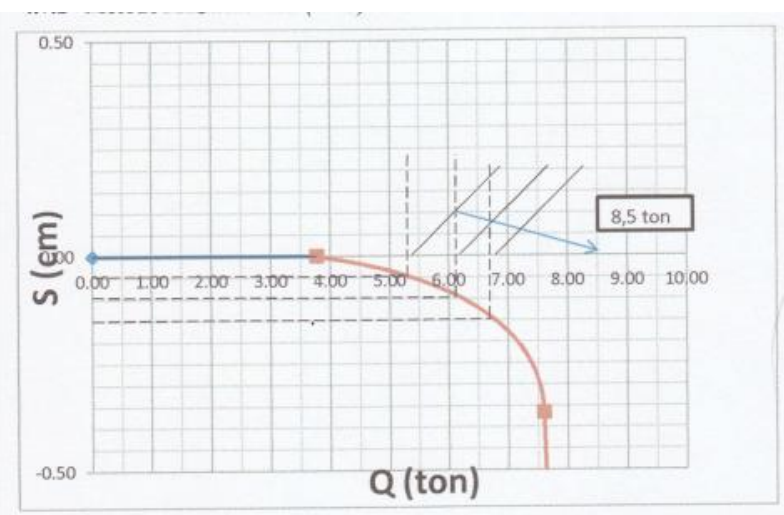

Sumber : hasil perhitungan

Gambar 9 Daya Dukung Tiang B1 Metode Mazurkiewich

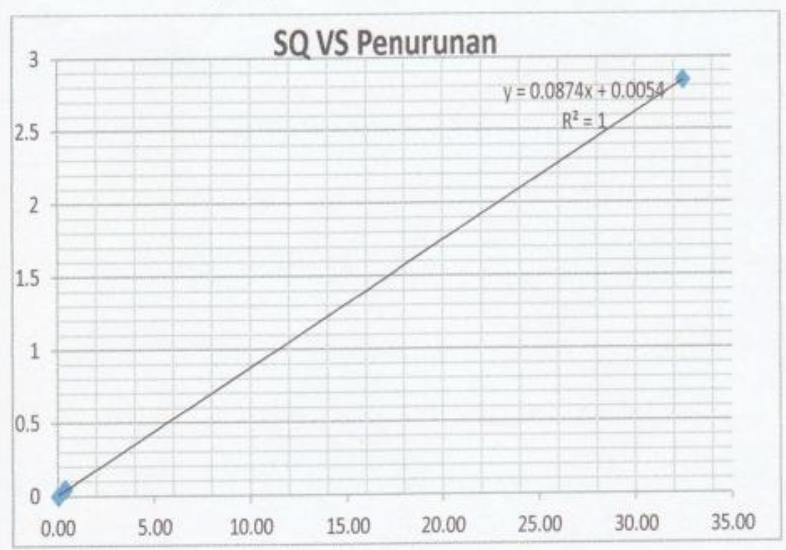

Sumber : hasil perhitungan

Gambar 10 Daya Dukung Tiang B1 Metode Chin

Tabel 1 Hasil Perhitungan Daya Dukung Tiang B1

\begin{tabular}{|c|l|c|c|}
\hline \multirow{2}{*}{ Konfigurasi } & Metode & $\begin{array}{c}\boldsymbol{Q}_{u} \\
\text { (ton) }\end{array}$ & Pola Keruntuhan \\
\hline \multirow{2}{*}{$\begin{array}{c}181 \\
20 \times\end{array}$} & Davisson & 7,70 & Plastis \\
\cline { 2 - 4 } $20 \mathrm{~cm}$ & Mazurkiewich & 8,50 & Plastis \\
\cline { 2 - 4 } & Chin & 9,50 & Plastis \\
\hline \multicolumn{2}{|l}{ Sumber : hasil perhitungan }
\end{tabular}

Tabel 2 Hasil Perhitungan Daya Dukung Tiang B3

\begin{tabular}{|c|c|c|c|}
\hline Konfigurasi & Metode & $\begin{array}{l}\boldsymbol{Q}_{u} \\
\text { (ton) }\end{array}$ & Pola Keruntuhan \\
\hline B3 & Davisson & 11,60 & Plastis \\
\cline { 2 - 4 } $28 \mathrm{~m}$ & Mazurkiewich & 11,00 & Plastis \\
\cline { 2 - 4 } $20 \times 20 \mathrm{~cm}$ & Chin & 9,80 & Plastis \\
\hline
\end{tabular}

Sumber : hasil perhitungan

Tabel 3 Hasil Perhitungan Daya Dukung Tiang E2

\begin{tabular}{|c|c|c|c|}
\hline \multirow{2}{*}{ Konfigurasi } & Metode & $\begin{array}{l}\boldsymbol{Q}_{u} \\
\text { (ton) }\end{array}$ & Pola Keruntuhan \\
\hline $\mathbf{E 2}$ & Davisson & 6,70 & Plastis \\
\cline { 2 - 4 } $20 \mathrm{~m}$ & Mazurkiewich & 6,80 & Plastis \\
\cline { 2 - 4 } $20 \mathrm{~cm}$ & Chin & 5,60 & Plastis \\
\hline
\end{tabular}

Sumber : hasil perhitungan
Tabel 4 Hasil Perhitungan Daya Dukung Tiang E4

\begin{tabular}{|c|c|c|c|}
\hline \multirow{3}{*}{ Konfigurasi } & Metode & $\begin{array}{l}\boldsymbol{Q}_{u} \\
\text { (ton) }\end{array}$ & Pola Keruntuhan \\
\hline \multirow{2}{*}{$\begin{array}{c}\text { E4 } \\
12 \mathrm{~m}\end{array}$} & Davisson & 6,50 & Plastis \\
\cline { 2 - 4 } $20 \times 20 \mathrm{~cm}$ & Mazurkiewich & 4,60 & Plastis \\
\cline { 2 - 4 } & Chin & 5,80 & Plastis \\
\hline
\end{tabular}

Tabel 5 Hasil Perhitungan Daya Dukung Tiang I

\begin{tabular}{|c|c|c|c|}
\hline Konfigurasi & Metode & $\begin{array}{c}\boldsymbol{Q}_{u} \\
\text { (ton) }\end{array}$ & Pola Keruntuhan \\
\hline $\begin{array}{c}\text { I } \\
18 \mathrm{~m}\end{array}$ & Davisson & 12,00 & Plastis \\
\cline { 2 - 4 } $20 \times 20 \mathrm{~cm}$ & Mazurkiewich & 13,00 & Plastis \\
\cline { 2 - 4 } & Chin & 12,70 & Plastis \\
\hline
\end{tabular}

Tabel 6 Hasil Perhitungan Daya Dukung Tiang G

\begin{tabular}{|c|c|c|c|}
\hline \multirow{2}{*}{ Konfigurasi } & Metode & $\begin{array}{l}\boldsymbol{Q}_{u} \\
\text { (ton) }\end{array}$ & Pola Keruntuhan \\
\hline \multirow{2}{*}{$\begin{array}{c}\text { G } \\
12 \mathrm{~m}\end{array}$} & Davisson & 6,70 & Plastis \\
\cline { 2 - 4 } $20 \times 20 \mathrm{~cm}$ & Mazurkiewich & 6,80 & Plastis \\
\cline { 2 - 4 } & Chin & 8,10 & Plastis \\
\hline
\end{tabular}

Perbandingan Daya Dukung Tiang

Tabel 7 Perbandingan Nilai Daya Dukung Tiang B

\begin{tabular}{|c|c|c|c|c|}
\hline No & $\mathbf{T}$ & Metode & $\begin{array}{l}\text { Daya Dukung } \\
\text { (ton) }\end{array}$ & $(\%)$ \\
\hline \multirow{2}{*}{1} & \multirow{6}{*}{ B1 } & Davisson MT & 7,70 & \multirow{2}{*}{49,80} \\
\hline & & Schmertmann-Nottingham & 15,34 & \\
\hline \multirow{2}{*}{2} & & Mazurkiewich & 8,50 & \multirow{2}{*}{44,59} \\
\hline & & Schmertmann-Nottingham & 15,34 & \\
\hline \multirow{2}{*}{3} & & Chin & 9,50 & \multirow{2}{*}{38,07} \\
\hline & & Schmertmann-Nottingham & 15,34 & \\
\hline \multirow{2}{*}{4} & \multirow{6}{*}{ B3 } & Davisson & 11,00 & \multirow{2}{*}{28,29} \\
\hline & & Schmertmann-Nottingham & 15,34 & \\
\hline \multirow{2}{*}{5} & & Mazurkiewich & 11,50 & \multirow{2}{*}{25,03} \\
\hline & & Schmertmann-Nottingham & 15,34 & \\
\hline \multirow{2}{*}{6} & & Chin & 9,80 & \multirow{2}{*}{36,11} \\
\hline & & Schmertmann-Nottingham & 15,34 & \\
\hline
\end{tabular}

Tabel 8 Perbandingan Nilai Daya Dukung Tiang E

\begin{tabular}{|c|c|c|c|c|}
\hline No & $\mathbf{T}$ & Metode & $\begin{array}{l}\text { Daya Dukung } \\
\text { (ton) }\end{array}$ & $(\%)$ \\
\hline \multirow{2}{*}{1} & \multirow{6}{*}{ E2 } & Davisson MT & 7,60 & \multirow{2}{*}{19,06} \\
\hline & & Schmertmann-Nottingham & 9,39 & \\
\hline \multirow{2}{*}{2} & & Mazurkiewich & 7,70 & \multirow{2}{*}{17,99} \\
\hline & & Schmertmann-Nottingham & 9,39 & \\
\hline \multirow{2}{*}{3} & & Chin & 5,60 & \multirow{2}{*}{40,36} \\
\hline & & Schmertmann-Nottingham & 9,39 & \\
\hline \multirow{2}{*}{4} & \multirow{6}{*}{ E4 } & Davisson MT & 6,50 & \multirow{2}{*}{30,77} \\
\hline & & Schmertmann-Nottingham & 9,39 & \\
\hline \multirow{2}{*}{5} & & Mazurkiewich & 4,39 & \multirow{2}{*}{53,25} \\
\hline & & Schmertmann-Nottingham & 9,39 & \\
\hline \multirow{2}{*}{6} & & Chin & 5,80 & \multirow{2}{*}{38,23} \\
\hline & & Schmertmann-Nottingham & 9,39 & \\
\hline
\end{tabular}


Tabel 9 Perbandingan Nilai Daya Dukung Tiang G

\begin{tabular}{|c|c|c|c|c|}
\hline No & $\mathbf{T}$ & Metode & $\begin{array}{c}\text { Daya Dukung } \\
\text { (ton) }\end{array}$ & $(\%)$ \\
\hline \multirow{2}{*}{1} & \multirow{6}{*}{ G } & Davisson & 6,70 & \multirow{2}{*}{28,65} \\
\hline & & Schmertmann-Nottingham & 9,39 & \\
\hline \multirow{3}{*}{2} & & Mazurkiewich & 6,80 & \multirow{2}{*}{27,58} \\
\hline & & Schmertmann-Nottingham & 9,39 & \\
\hline & & Chin & 7,40 & \multirow{2}{*}{21,19} \\
\hline 3 & & Schmertmann-Nottingham & 9,39 & \\
\hline
\end{tabular}

Tabel 10 Perbandingan Nilai Daya Dukung Tiang I

\begin{tabular}{|c|c|c|c|c|}
\hline No & $\mathbf{T}$ & Metode & $\begin{array}{c}\text { Daya Dukung } \\
\text { (ton) }\end{array}$ & $(\%)$ \\
\hline \multirow{2}{*}{1} & \multirow{6}{*}{ I } & Davisson & 12,00 & \multirow{2}{*}{21,77} \\
\hline & & Schmertmann-Nottingham & 15,34 & \\
\hline \multirow{2}{*}{2} & & Mazurkiewich & 13,00 & \multirow{2}{*}{15,25} \\
\hline & & Schmertmann-Nottingham & 15,34 & \\
\hline \multirow{2}{*}{3} & & Chin & 12,80 & \multirow{2}{*}{16,55} \\
\hline & & Schmertmann-Nottingham & 15,34 & \\
\hline
\end{tabular}

\section{KESIMPULAN}

Dari hasil perhitungan teoretis, didapat daya dukung ultimit tiang pancang metode SchmertmannNottingham pada kedalaman $12 \mathrm{~m}$ sebesar 9,39 ton, dan kedalaman $18 \mathrm{~m}$ sebesar 15,34 ton. Perbedaan daya dukung ultimit yang paling besar terjadi pada tiang E4 kedalaman $12 \mathrm{~m}$, antara metode SchmertmannNottingham dan Mazurkiewich, sebesar 53,25\%. Perbedaan daya dukung ultimit paling kecil terjadi pada tiang I kedalaman $18 \mathrm{~m}$, yaitu antara metode Schmertmann-Nottingham dengan metode Mazurkiewich, sebesar 15,25\%. Karena terjadi perbedaan yang sangat signifikan antara dua hasil perhitungan (teoretis dan aktual), maka disarankan, pada setiap melakukan pemancangan tiang, agar dilakukan loading test.

\section{REFERENSI}

Guy, S., Olivari, G., Bernard C., 1989. Mekanika Tanah dan Teknik Pondasi, Erlangga, Jakarta

GEC UNPAR. 2005. Manual Pondasi Tiang, UNPAR, Bandung

Hardiyatmo, H.C. 2014. Analisis dan Perancangan Pondasi I, Edisi ke-3, Gajah Mada University Press, Yogyakarta

Hardiyatmo, H.C. 2015. Analisis dan Perancangan Pondasi II, Edisi ke-3, Gajah Mada University Press, Yogyakarta

Noor, A., Octavian, S., 2014. Evaluasi Perkiraan Daya Dukung Teoretis Terhadap Daya Dukung Aktual Tiang Berdasarkan Data Sondir dan
Loading Test, Jurnal Intekna Tahun XIV, No. 1, Poliban Banjarmasin

Shirley, L.H. 1987, Geoteknik dan Mekanika Tanah, Nova, Bandung

Sardjono, H.S. 1991, Pondasi Tiang Pancang Jilid I, Sinar Wijaya, Surabaya

Sardjono, H.S. 1991, Pondasi Tiang Pancang Jilid II, Sinar Wijaya, Surabaya

Terzaghi, K., Ralph, B.P., 1967, Soil Mechanic in Engineering Practice, Second Edition, John Wiley\&Sons, New York 